News from Europe 


\section{Three International Congresses: Bratislava (1967), Vienna (1968), Austin (1969)}

During the past few years communications between historians of Eastern, Central, and Western Europe, and the United States have continually improved. Almost entirely absent at the international conferences at Bratislava, from August 28 to September 1, 1967; at Vienna, on October 2125, 1968; and at Austin, Texas, on April 18-20, 1969, were the ideological, political, and national polemics between Marxian Socialist and Western historians which all too frequently hindered the free and honest exchange of ideas at the international congresses of historical sciences at Rome, Stockholm, and Vienna. At Bratislava scholars from all ideological camps demonstrated much greater willingness to liberate themselves from the narrow confines of their own particular national and political creeds than they had at the international congress of historical sciences at Vienna just two years earlier. In Vienna the next fall, in spite of the shadow that hovered over the conference because of developments in Central Europe a few weeks earlier, there seemed to be even greater readiness to try to understand the other person's point of view than there had been at Bratislava. And at Austin in the spring of 1969 the atmosphere was almost that of a gathering of local fraternity men.

The first two of these three conferences were devoted to historical themes and were largely attended by historians from Central Europe. The one at Bratislava, which was organized and directed by Ludovít Holotík, was in commemoration of the centennial of the Austro-Hungarian Compromise of 1867. Attending the conference were approximately 125 historians, of whom 40 were Czechs and Slovaks. Among the Americans present were Stephen Fischer-Galati, of the University of Colorado; Keith Hitchins, of the University of Illinois; Charles and Barbara Jelavich, of Indiana University; Robert A. Kann, of Rutgers University; Suzanne G. Konirsh, of the College of Notre Dame; Ivo J. Lederer, of Stanford University; Charles Morley, of Ohio State University; Joachim Remak, of 
the University of California at Santa Barbara; Peter Sugar, of the University of Washington; Stanley Winters, of the Newark College of Engineering; Joseph Zacek, of the State University of New York at Albany; and the undersigned. Approximately half of the Americans at the conference presented written reports and all of them took part in the discussions.

The Bratislava conference was in many ways a model of what a centennial meeting should be-a genuine reappraisal rather than a mere "glorification" of a past epoch of history. Besides introductory and concluding sessions of a general nature, there were special programs on the international situation at the time of the Compromise; the social, economic, and constitutional problems involved; the effects of dualism on various nationalities in the Austro-Hungarian monarchy; and the problems of federalism that stemmed from the Compromise. Numerous participants offered first-rate contributions to the reevaluation of various aspects of the Ausgleich. Among the especially interesting contributions were Peter Hanák's "Die bürgerliche Umgestaltung der HabsburgerMonarchie und der Ausgleich;" Robert A. Kann's "The Austro-Hungarian Compromise of 1867 in Retrospect;" Jiř́ Kořalka's "Die preussisch-deutsche Politik, der Ausgleich von 1867 und die nationalen Fragen in Mitteleuropa;" Július Mésároš" "Die Stellung der Völker Osterreich-Ungarns nach dem Sturze des Absolutismus im Lichte der Angaben über die Entwicklung der Bevölkerung und des Schulwesens;" Peter Sugar's. "The Reaction of the Croats, Romanians and Slovaks to the Ausgleich, 1867-1875;" and Fran Zwitter's "Causes et conséquences du compromis austro-hongrois."

Six American and Canadian scholars (M. Kamil Djiewanowski, of Boston University; Robert A. Kann, of Rutgers University; Ivo J. Lederer, of Stanford University; Stanley. Z. Pech, of the University of British Columbia; Stephen Swift, of Sugar Land, Texas; and the undersigned) were among the approximately 75 Austrian and 75 non-Austrian historians in Vienna for the international conference devoted to a semicentennial reappraisal of the dissolution of the Habsburg monarchy. The congress was sponsored by the Osterreichisches Ost- und Südosteuropa-Institut and organized by Richard Plaschka, director of that institute, and Fritz Fellner, of the University of Salzburg. Two of the American historians pre- 
sented research papers at the conference.

The first day of the meeting was devoted to general introductory themes. Richard Plaschka spoke on "Die revolutionäre Herausforderung im Endkampf der Donaumonarchie:" and Fritz Fellner, on "Der Zerfall der Donaumonarchie in .weltgeschichtlicher Perspektive." In the evening Robert A. Kann lectured on "Das demokratische Prinzip im Widerstreits des Zusammenbruchs Österreich-Ungarns und des Aufbruchs der Nachfolgestaaten;" and Vladimir Turok talked on "Die russische Oktoberrevolution und ihre Rückwirkung auf den $\mathrm{Zu}$ sammenbruch der österreichischen Monarchie."

The sessions on October 21-24 were devoted to important aspects of the dissolution of the monarchy. At the first one, which was devoted to "Die diplomatische und militärische Entwicklung," the main papers were Bogdan Krizman's "Die Tätigkeit der österreichisch-ungarischen Diplomatie in den letzten Monaten vor dem Zusammenbruch," and Karel Pichlík's "Der militärische Zusammenbruch der Mittelmächte im Jahre 1918." Sixteen additional papers dealing with various facets of this general theme were presented by Austrian, British, Czechoslovak, French, Hungarian, Jugoslav, Polish, Romanian, and American historians. Next, the "Soziale und ökonomische Auswirkungen des Krieges und die revolutionären Erscheinungen in Europa" were discussed. György Ránki and Iván Berend contributed a main paper on "Die wirtschaften Probleme des Donaubeckens nach dem Zerfall der österreichisch-ungarischen Monarchie," and eight other historians from Austria, Czechoslovakia, Hungary, Jugoslavia, Poland, and Russia spoke on related topics. The last special theme of the conference dealt with "Demokratisierung der Mittelmächte-Entstehung der Nachfolgestaaten." Henryk Batowski gave a general paper on "Nationale Konflikte bei der Entstehung der Nachfolgestaaten." In addition, there were fourteen special reports by Austrian, British, Czechoslovak, German, Hungarian, Jugoslav, and Russian scholars. At the closing session on October 5, Friedrich Engel-Janosi gave a lecture entitled "Damals-Erinnerung eines Offiziers, Wertung des Historikers," and Erika Weinzierl talked on "Osterreich 1918-38. Konsequenzen für die Republik."

The conference held in Austin, Texas, was devoted to "EastCentral and Southeast European Geography." It was organized and directed by George W. Hoffman. Approximately 
40 persons, nearly all of them geographers, were invited to participate. Although the conference was largely attended by American scholars, four European geographers were present: Ivan Crkvenčic, of the University of Zagreb; F. E. Ian Hamilton, of the University of London; Koloman Ivanicka, of the University of Bratislava; and Adolf Karger, of the University of Giessen.

At all three of these conferences intellectuals from Eastern Europe freely exchanged views with those from Central and Western Europe and the United States and Canada. As a consequence, not only did individual scholars from countries with different economic, social, and political attitudes gain valuable and frequently fresh ideas with which to enrich their own studies but historical and geographical scholarship was greatly benefited as well. Let us hope that the coming International Congress of Historical Sciences at Moscow will continue along the same lines.

R. J. R. 